\title{
Loan Recovery Procedures in Tanzania: A Case of Selected Microfinance Institutions in Dar-Es-Salaam, Tanzania
}

\author{
Richard Sikira \\ Institute of Accountancy Arusha
}

\begin{abstract}
The study aimed to determine the procedures employed by MFIs, specifically in loan recovery in Tanzania. Loan recovery has been a difficult task for many financial institutions but becomes more challenging to microfinance institutions due to the nature and processes they employ. The study examined the loan recovery procedures at NFBS, SMF and AML found in Dar-Es-Salaam, Tanzania. The researcher employed a mixed-case study design, which involved 50 credit officer respondents obtained under the purposive sampling. The study used semi-structured questionnaires to gather primary data and also secondary data from documents available at NFBS, SMF and AML. Data were analysed using simple descriptive statistics with percentages and frequencies for quantitative data, while thematic analysis was used for qualitative data. The study found that NFBS, SMF and AML used loan recovery procedures such as direct contact, friendly reminder, and issuance of final demand notice. Another procedure is to inform the local government on property selling and using a debt collection agency. The study recommends for MFIs to establish and prefer formal procedures that can be used for loan recovery because the use of informal procedures creates room for conflict and leads to ineffectiveness of recovering loans.
\end{abstract}

\section{Introduction}

The issue of loan recovery has emerged to be a matter of concern among financial institutions globally (Kaveri, 2016; Sah, 2015). The essence results from the critical position occupied by loans in determining any financial institution's financial health status (Messai \& Jouini, 2013; Ozili, 2019; Waqas et al., 2019). Although loan recovery is a global challenge, it is even more complicated in poor and developing countries and specifically among microfinance institutions (MFIs) than commercial banks (Ali, 2014; Chen et al., 2019; Rehman et al., 2016). The challenge is attributed to internal procedural weakness, which is evident in many MFIs in developing countries (Kimasar, 2014; Sarma \& Borbora, 2014). Loan recovery refers to the totality of efforts initiated by the lender to ensure the borrower repays the borrowed money as per agreed terms and conditions (Kaveri, 2016; Khalily \& Meyer, 1993; Sah, 2015). For the loan recovery to be implemented, MFIs need to ensure the availability of solid policies through which guidelines and procedures emanate (Marini et al., 2017; Osunde \& Mayowa, 2012). Moreover, this is the heart of loan recovery in loan recovery where success or failure of the process can be traced from this component.

MFIs require a competent workforce for loan recovery on top of the available policies and guidelines (Gachuru, 2020). Without personnel who possess the proper knowledge, skills and attitude about loan issues and recovery tasks, the MFI will be digging its own business grave.

The MFIs need to ensure their internal environments are conducive and conform to the external environment that includes abiding by government rules and regulations (Osunde \& Mayowa, 2012; Rao \& Sravani, 2013; Risal, 2018). Thus, following recovery rules in the loan recovery process is both interlinked with internal and external procedures. 
The loan recovery procedures have one primary objective for MFIs to ensure loans are recovered effectively and efficiently (Sah, 2015). It is useless for an institution to have internal procedures that do not contribute to the loan recovery's effectiveness and efficiency. Weak internal procedures will render loss and finally closure of the business; hence, loan recovery is vital in MFIs. The better the procedure, the easy the recovery of loans

The purpose of the paper is to determine the procedures used for loan recovery among selected MFIs in DarEs-Salaam, Tanzania, namely Nuru Financial and Business Services (NFBS), Self-Microfinance Fund (SMF) and Ameic Microcredit Limited (AML).

This paper covers the following sections; abstract, introduction, literature reviews, findings of the study, discussion of the study, conclusion, and recommendations.

\section{Literature Review}

2.1. Literature Review

2.2. Overview of Micro Finance Institutions Genesis in Tanzania

MFIs have a long history of over 25 years of operation in Tanzania since 1995 when savings and credit cooperative organisations (SACCOS) started to operate in the country. Other forms of MFIs such as microfinance NGOs and microfinance companies conducted their business during that time (Brown et al., 2015a; MFT, 2011)

Predominantly, there were pioneer MFIs such as Tunakopesha, which was established in 1992, Yetu finance was established in 1997, and Finca microfinance was established in 1998 (Brown et al., 2015b; MFT, 2011). Among all the pioneer MFIs during the 1990s, Finca set the standard which primarily set the basis for the current microfinance operations in Tanzania. In the early 2000s, there was an increase in MFIs that occupied 25\% of all customers in Tanzania's financial sector (WB, 2013).

MFIs, like any other business, aim at getting profit from the service they offer. In such an essence, Tanzania witnessed MFIs' mushrooming in the 2000s, where poverty alleviation programmes were on the core government agenda. Microfinance business's potential is reflected through the Vision 2025 in government programmes aiming to eradicate poverty and enhance economic development like Mkukuta, Mkurabita and others (URT, 2000). These programmes, among other things, intended to enhance poverty eradication through the availability of credit facilities to all Tanzanian classes.

For MFIs to tape the available growth opportunities supported by the government initiatives, MFIs had to find financial capital through banks such as NMB, NBC and CRDB. The initiatives to seek external financial capital result from weak financial muscles among many MFIs hence relying on commercial banks for capital. In 2019, banks such as CRDB extended 8.2\% more loans and advances to customers, including MFIs in Tanzania (CRDB, 2020).

At all times, through the Ministry of Finance, the government sets rules, regulations and acts on microfinancing services in collaboration with the parliament and other stakeholders (Brown et al., 2015b). After setting the rules and regulations, the Bank of Tanzania (BOT) acts as a regulator for all financial institutions in the country through microfinance supervision committees (BoT, 2019).

\subsection{Legal Aspect in Loan Recovery Procedures in Tanzania}

The usual antagonistic relationship between a lender and loan beneficiary is evident in most povertystricken communities in developing countries such as Tanzania. The lender wants to maximise profit by charging high accumulating interest rates monthly, and the loan beneficiary wishes to escape after getting a loan. Such an antagonistic context requires a robust legal framework to ensure and protect the 
weaker part's rights and the loan beneficiary and on the other side, the creditor, which is the stronger party in this matter.

As highlighted previously, the legal framework for loan recovery emerges from the Ministry of Finance, the Parliament and the BOT, who offer guides through the Microfinance Policy of 2017, Microfinance Act of 2018, and Microfinance Regulations of 2019. The foundation for the new microfinance framework started in 2017 when the National Microfinance policy was adopted. The policy intended to create a conducive environment for MFIs through their products and services (BoT, 2019).

In the Microfinance Act of 2018, it is provided in section 51 that loan recovery has to abide by proper procedures such as issuing a written notice to the debtor, and in case the debtor's property has to be sold, this has to be the last resort, and more importantly, the selling procedures must be followed (Microfinance Act, 2018). If the MFI is not following such procedures during recovery, a penalty shall be applied to it.

Additionally, the Microfinance Regulations of 2019 section 79 provide the details on consumer protection during debt collection or recovery. In this section, stricter procedures protecting the debtor, such as offering a 14 days' notice on loan recovery (Microfinance Regulations, 2019). Also, the section prohibits any form of violence or harassment to the debtor.

In such a context, a legal provision serves to protect MFIs' loan consumers through a fair platform that ensures the debtors and creditors' rights are protected. Without such provisions, harmony is at stake.

\subsection{The Key Issues in Loan Recovery Procedures}

Banks and MFIs usually experience difficult times regarding loan recovery as they are demanding customers who default to repay their loans as per an agreement (Kartikasary et al., 2020). The microfinance demand for repayment leads to a necessary establishment of various loan recovery strategies (Ali, 2014), some of which appear to be effective while others are not. In a study on loan recovery by Laseinde and Olokoyo (2018), it was found that using the traditional and common approach to harass defaulters with letters, calls, and closing their business has proved to be ineffective in recovering their loans. The study recommends using a solid customer relationship, which will first seek to determine early problems of defaulters and secondly find a better way to manage them.

\subsubsection{Factors Affecting Loan Recovery Procedures}

As banks and other financial institutions struggle to recover their loans, it is worth pondering the critical factors leading to loan delinquency Gikurumi et al. (2015), which further necessitates a loan recovery exercise. In the study on determinants of loan recovery rates by Wang et al. (2020), it was found that the loan recovery rates differ depending on the economic cycle. The study places economic factors as significant factors affecting loan recovery compared to other factors, which are less intense loan recovery determinants. That means banks and other financial institutions should expect lower loan recovery rates when economic times are more rigid on local, national and even international levels.

Recovering loans from a group loan may be different from the employee and company loans recovering process in which factors determining the repayment may be different (Neilands, 2018; Pandey, 2019; Thomas \& Thakur, 2019). Several studies conducted in Kenya, Burkina Faso and Tanzania revealed that loan recovery through group repayment is positively determined by peer pressure, rules of the group, and belongingness to the same business, the level of knowing each other, sex, education and others (Angaine \& Waari, 2014; Kitomo et al., 2020; Paxton et al., 2000). Therefore, the determinants of loan recovery are collective and not individualistic. Furthermore, in group loan, the loan officer's role and relationship substantially impact recovering loans from the group. 
Sometimes loan defaulting is contributed by credit institutions, especially when they ignore credit risk management (Torban, 2020). A study by Gatimu and Kalui (2014) revealed that when credit risk management concerning policy, procedures, and appraisal processes are ignored, defaulting is an immediate outcome to expect. Thus, it requires financial institutions to restructure their loans in some ways possible to enhance the recovering process for their survival (Fenech et al., 2016). It is relevant for microfinance to consider their risk management to avoid losses and simplify the loan recovery process whenever needed.

Recovering loans among small scale farmers is a challenging task that needs commitment and innovation. A study conducted in Ethiopia by Gebeyehu et al. (2013), using regression analysis, identified factors influencing loan repayment and loan recovery among smallholder farmers in Kalu, Ethiopia. The study found that the land size owned by the family, agricultural experience, the aim of borrowing, and the loan's origin positively affected the repayment of loans, hence triggering loans recovery. The innovation in loan recovery seems crucial as situations can easily change and render farmers a genuine reason not to repay their loans. In Uganda, subsistence farmers' experience through BRAC loans, weekly repayment has guaranteed loan recovery; however, borrowers, especially women, stop borrowing due to associated repayment stress (Namayengo et al., 2016). Microfinance needs to rethink loan issuing, repayment and recovery strategies in serving smallholder farmers.

Loan defaulting as an immediate sign that necessitates loan recovery can be contributed by so many factors, as highlighted in the study conducted in Ghana using regression analysis. Mensah et al. (2015) indicated that loan defaulting is contributed by higher interest rates, moral hazards, and over-borrowing habits among customers. Furthermore, when loan beneficiaries are not visited frequently and when loans are not associated with collateral, the possibility of defaulting is higher.

Several studies conducted in Kenya show the challenges farmers face in accessing loans and other financial services as over 80\% of farmers cannot access such services (Kiplimo, 2015; Kosgey, 2013). However, in another study by Yegon et al. (2013) in Kenya, loan repayment among farmers is significantly affected by personal and loan facility conditions and not farming conditions; hence, this attracts loan defaulting and, ultimately, loan recovery.

The study by Ongesa et al. (2014) enlightens a crucial educational factor that affects both repayment of loans and the recovery process. Microfinance loans are typically designed and accessed by most poor entrepreneurs whose level of education is limited. Most of these beneficiaries lack crucial business skills such as bookkeeping, budgeting and managing their loans which cause loan mismanagement, repayment failure and finally, loan recovery initiatives.

Many studies explain the factors affecting loan repayment among entrepreneurs and small rural farmers. In addition to many other common factors discussed previously, Nguta Guyo and Huka (2013) conducted a study in Kenya with 400 persons sample size using a survey design that revealed technical advice and business training have a crucial role in determining loan repayment. To avoid extra costs incurred during loan recovering processes, it is crucial to invest in technical training and support for credit beneficiaries to enhance smooth repayment.

\subsubsection{Practices of Loan Recovery Procedures}

A study by Chisom (2012) on loan granting and its recovery problems in Nigeria sheds some crucial facts on banks and other financial institutions' various loan recovery measures. It was revealed that some of the recovery measures taken by these financial institutions are such as sending demand notices to defaulters. This demand notice acts as a reminder message to honour the loan contract which was agreed before issuing loans, of which failure to honour it calls upon enforcing legal action. Another 
approach is acquiring and selling the collateral. Collateral selling is a crucial resort taken by credit institutions to ensure that the value of loan issued plus interest is returned to the bank as failure to do, the loss will be realised on the side of the lender. The last resort for many creditors is taking strict legal action against defaulters to make sure the loan is recovered. Here the court of law processes will be involved through which the judge will issue a ruling that will be honoured by both parties.

Various studies have discussed loan recovery, which has been labelled as challenging and problematic (Makorere, 2014). Scholars who discussed loan recovery strategies assert that different organisations use different approaches to recover their money based on the policy they follow, which calls for the necessity to establish necessary procedures. It has been noted that the process to recover a loan starts immediately when the loan beneficiary starts to default. Regarding a defaulting incidence, the literature reveals that the situation can be propagated by economic factors, as advocated by (Wang et al., 2020). These include creditors' factors such as higher interest rates, disbursement delays, lack of training and follow-ups, or can be propagated just by moral values, including the loan beneficiaries' attitude (Netzer et al., 2019; Priyankara \& Sumanasiri, 2019; Zhang et al., 2019).

It is common in some developing countries to incorporate illegal loan recovery strategies such as threatening and confiscating creditors' properties unfairly (Krishnan \& Kozhikode, 2015). The approach is contrary to humanistic ways of loan recovery, such as employing ethical negotiation and improved repayment schemes (Amirah \& Hanani, 2018).

Procedures for loan recovery seem to contribute to the financial institutions' dreadful costs (Okwara et al., 2019). Apart from the direct monetary expenses attached to paying the legal team, recovery officials and companies, the customer relationship is also suffering adversely (Wang et al., 2020). On that account, financial institutions need to be considerate in choosing their recovery strategies regarding customer relationship (Laseinde \& Olokoyo, 2018).

Loan recovery procedures are noted to play a critical role in loan delinquency. The catastrophe means whenever loan recovery procedures are intimidating and unprocedural; loan delinquency is an outcome of such acts (Gikurumi et al., 2015). However, when rigorous loan recovery procedures are intact, including adherence to reporting system as evidenced by MENA countries and BRAC microfinance in Uganda, repayment of loans is guaranteed (Ghosh, 2019; Namayengo et al., 2016).

Governments in the world have established procedures to be followed by financial institutions in loan recovery, as in the case of Srilanka (Rathnapala, 2015), where there is a length of loan recovery procedures involving various authoritative institutions. The scenario is similar to Malaysia with the Islamic banking system. However, despite the procedures and mechanisms stipulated under the law, financial institutions do not adhere to those procedures fully on Islamic financial loans (Amirah \& Hanani, 2018). This non-adherence to loan recovery procedures ultimately affects loan recovery and leads to non-performing loans.

\subsection{Methodology}

This section covers the study's design, sample size and sampling techniques, data collection methods, and data analysis techniques.

\subsection{Research Design}

In the course of conducting the study, the researcher employed a mixed-method case study design. A mixed-method case study design is a research design that applies both qualitative and quantitative approaches in collecting and analysing data for a deeper understanding of the phenomenon and comparing cases (Guetterman \& Fetters, 2018). Therefore, this method was chosen because it enables an in-depth study of the phenomenon. 


\subsection{Sample Size}

The study selected 50 respondents to participate in the study out of 84 persons who compose the whole study population. The population which comprises respondents are loan officers in NFBS, SMF, and AML. As Kothari (2004) supported, a 10\% sample size of the whole population under study is representative and suitable. The chosen sample size is $59.5 \%$ of the population. As the study employed a case study design, the sample size was taken due to saturation, whereby the researcher noted the information was enough to facilitate the study.

\subsection{Sampling Techniques}

Based on the nature of the study, the researcher employed purposive sampling. This non-probability sampling technique was explicitly used to approach respondents to get all information as per study objectives. This technique was therefore used for all credit officers who are the respondents under the study.

\subsection{Methods of Data Collection}

The study employed both primary and secondary data collection methods. This study's primary data were gathered through the semi-structured questionnaires, which contained both open-ended and closed-ended questions, capturing quantitative and qualitative data. The study collected secondary data such as policies, literature, and reports to complement the collected primary data.

\subsection{Data Analysis Methods}

The study used both qualitative and quantitative approaches for analysing collected data. Through the quantitative approach, collected data were first coded and later analysed using simple descriptive statistics such as percentages and frequencies. For the qualitative approach, the study applied the content analysis approach, a suitable data analysis method in qualitative studies (Creswell \& David Creswell, 2018).

\subsection{Findings}

This study aimed to determine the procedures for loan recovery among MFIs in Tanzania. The following are the specific findings noted as illuminated in Table 1.0 below;

\section{Table 1:0 Procedures for Loan Recovery}

\begin{tabular}{|c|c|c|c|c|c|c|c|}
\hline \multicolumn{8}{|c|}{$\mathrm{N}=50$} \\
\hline $\mathrm{S} / \mathrm{N}$ & Procedure & Yes & $\%$ & No & $\%$ & Not Sure & $\%$ \\
\hline \multirow[t]{2}{*}{1} & Use of direct contact as a procedure for loan & 50 & 100 & 0 & 0 & 0 & 0 \\
\hline & recovery & & & & & & \\
\hline 2 & Use of a friendly reminder on phone & 46 & 92 & 2 & 4 & 2 & 4 \\
\hline 3 & $\begin{array}{l}\text { Issue of final demand notice as a procedure for a } \\
\text { loan recovery }\end{array}$ & 35 & 70 & 10 & 20 & 5 & 10 \\
\hline 4 & Inform local government on the selling of property & 30 & 60 & 18 & 36 & 2 & 4 \\
\hline 5 & Use a debt collecting agency & 26 & 52 & 14 & 28 & 10 & 20 \\
\hline
\end{tabular}

Source: Author (2020)

\subsection{Direct Contact with Customers}

According to Table 1.0, the study found that direct contact with customers was the most prominent 
procedure used by loan officers to recover loans. This fact is evidenced by responses from 50 (100\%) respondents who stated that they use this approach to recover loans. Furthermore, the respondents asserted that they visit their customers in their workplaces and sometimes go to their homes. Furthermore, respondents provided the reason for using direct contact in the loan recovery process due to failure to pay loans according to the agreed schedule. In such a context, it is essential to make direct contact to know precisely why the client failed to pay a loan and agree on the possible use of amicable strategies to recover loans.

The above findings show that most respondents prefer to use direct contact with the customers for loan recovery tasks. The use of this procedure implies that it is very effective compared to other procedures used by NFBS, SMF and AML. Therefore, it can be argued that using a phone call to make loan followup may not work as

\subsection{Use of Friendly Reminder on Phone}

Apart from the above-presented procedure of direct contact with customers to recover loans, loan officers' second preferred procedure, as presented in Table 1.0, is the use of friendly reminders through phone calls. This response is supported by 46 (92\%) from NFBS, SMF and AML, who asserted that they use a friendly reminder on the phone as a procedure for loan recovery. Apart from those who agreed to use a friendly reminder on the phone, other $2(4 \%)$ respondents disagreed about using a friendly reminder. Otherwise, the other $2(4 \%)$ asserted that they are not sure about using this approach. In additional details, respondents provided that phone reminders are a good startup approach for loan recovery, although it can be challenging as a loan defaulter can decide to switch off the phone. Furthermore, respondents provided that a phone reminder is the first determinant that the customer is willing or unwilling to pay the loan and whether there is a need to establish a better means to deal with such a client. They also provided that although many loan officers prefer phone reminders, it has 'fiftyfifty' chances of success.

The above findings confirm that loan officers in the selected MFIs use a friendly phone reminder as a procedure for loan recovery. According to this study, this is the second most used procedure for loan recovery.

The findings imply that friendly approaches have their significance regarding loan recovery. Loan officers should call customers who take loans and get on the brink of defaulting before using other coercive methods to recover loans. These approaches work, although not always but at least set a platform for applying different procedures.

\subsection{Issue of Final Notice}

In addition to the above procedures, the study also intended to explore whether MFIs under the study issue a final demand notice to customers regarding loan recovery. The study found that 35 (70\%) respondents commented that they issue demand notices to customers as a procedure for loan recovery from their clients. Other $10(20 \%)$ respondents disagreed with issuing the final notice, while 5 (10\%) respondents were not sure regarding the use of final notice to effect loan recovery. Furthermore, respondents clarified that the final notice is the alerting call which many customers take it seriously as it prompts further coercive action if the loan beneficiary does not take immediate measures.

The above findings provide that loan recovery final notice is among the loan recovery approaches and hence preferred by loan officers, as noted in the above presentation. This finding implies that loan recovery procedures sometimes need to be extreme and include some coercive actions to the customer so that the loan can be recovered as required. Hence,

to attain this, a final demand notice which directs legal action is the way to go. 


\subsection{Inform Local Government on the Selling of Property}

Sometimes customers do not respond to humanistic procedures for loan recovery. This reluctance necessitates the application of further procedures, which many customers do not prefer. Some of these include informing the local government authorities at the village and sub-village levels about the issue. In this regard, it was found that the procedure to inform local government authorities was preferred by about $30(60 \%)$ credit officers who agreed that they use it as an approach to recover loans. Other 18 (36\%) and $2(4 \%)$ respondents disagreed and were not sure respectively of informing the local government as a procedure for loan recovery.

The findings reveal that informing the local government was the fourth preferred means of loan recovery. Informing local government is somehow an unpopular procedure compared to previously presented procedures with a higher agreement level. This situation implies that all possible procedures are used in loan recovery as long as they lead to recovering of loans, and even though they may seem unpleasant to a defaulting customer, they can serve the purpose.

\subsection{Use a Debt Collecting Agency}

The findings in Table 1.0 depict that $26(52 \%)$ respondents revealed that MFIs use collection agency as a last resort for the loan recovery procedure. However, $14(28 \%)$ respondents disagreed that they use debt collection agencies for collecting loans, while other 10 (20\%) respondents were not sure whether they use debt collection agencies for loan recovery. Additionally, respondents clarified that they use a debt collection agency when the regular efforts prove futile and unsuccessful. Hence, they apply this coercive procedure to recover loans. Respondents explained more on how this happens that after the court of law issues an order for such an action, a contracted debt collection agency does the work on behalf of the MFIs.

The above findings reveal that debt collection agencies' services to recover loans are rarely used by MFIs, as noted in the above presentation. According to this study, this procedure seems to be the most unpopular and least applicable by MFIs than other procedures revealed previously by respondents. It is, therefore, the least preferred among loan recovery procedures presented above. This finding implies that, although this procedure is used, in most cases, credit officers recover loans earlier before using debt collection agencies for such an action. Moreover, when this approach is used, it is meant to be the last resort that aims at preventing further losses on the side of the lender.

\subsection{Discussion}

\subsection{Direct Contact with Customers}

In this section, the study established that direct contact with customers was the most prominent procedure used by loan officers to recover loans. The evidence is revealed by responses from all 50 $(100 \%)$ respondents who stated that they use this loan recovery procedure. The above findings correspond to the literature as noted in the study conducted by Chisom (2012) in Nigeria, whereas it was found that the direct contact procedure for loan recovery is crucial and should be within the legal framework and adhere to professionalism. The study further provided that direct communication with customers creates a basis for successful loan recovery. The above findings from respondents and literature revealed that most respondents prefer to use direct contact with the customers for loan recovery tasks. The use of this procedure implies its effectiveness compared to other procedures among NFBS, SMF, and AML; hence, all respondents agreed to use it for loan recovery.

\subsection{Use of Friendly Reminder on Phone}

The study found that using friendly reminders on the phone for loan recovery was the second preferred procedure used by loan officers in the selected organisations. $46(92 \%)$ respondents supported this 
response from NFBS, SMF and AML, who asserted that they use a friendly reminder on the phone as a procedure for loan recovery. The above finding concurs with Wilfred (2013), who revealed that using the phone in making follow-ups in loan-related matters could be a good approach to establish relations and set a basis for a possible meeting between a client and loan officers. The outcome of phone communication can simplify the meeting session; however, sometimes relying on phone communication alone does not yield results.

The above findings from respondents and literature confirm that loan officers in MFIs use a friendly phone reminder as a procedure for loan recovery. The above findings imply that a friendly reminder on the phone is a necessary procedure used for loan recovery as sometimes it is very effective, although sometimes it may not be effective. However, it sets a foundation for other aggressive procedures for loan recovery.

\subsection{Issue of Final Notice}

The study further noted that the issuance of final demand notice to customers was the third loan recovery procedure used by the selected organisations. The study specifically found that $35(70 \%)$ respondents commented that they issue demand notice to customers as a procedure for loan recovery from their clients. In the literature, the issuance of final notice is a common approach used by financial institutions, as noted in the study by Debeb (2015), who asserted that sometimes loan beneficiaries do not abide by their contract, such that issuing a final notice might help loan beneficiaries to pay their loans. Another study by Islam et al. (2018) revealed that issuing a final notice to customers to recover a loan is a prevalent practice among financial institutions, and sometimes, the process leads to the use of force which later affects customers. The above findings from respondents and literature reveal that issuing a final notice to loan beneficiaries is among the loan recovery procedures used by loan officers in many places to enhance loan recovery. This finding implies that loan recovery procedures sometimes need to be extreme and include some coercive actions to the customer so that the loan can be recovered as required. Therefore, a final demand notice which directs legal action is the way to go.

\subsection{Inform Local Government on the Selling of Property}

The fourth procedure is informing local government authorities on the selling of the defaulted client's property. The event happens because sometimes customers do not respond to procedures for loan recovery. The trend necessitates further procedures that many customers do not prefer, such as informing the local government authorities in the village and sub-village level about the issue. In this regard, most credit officers preferred the procedure to inform local government authorities; about 30 $(60 \%)$ of respondents agreed that they used it as an approach to recover loans.

The study by Murthy et al. (2017) highlights the government's interference and support on loan recovery initiatives as done by the Malaysian government. Through the government's support, identification of loan defaulters and associated conditions for loan recovery was made possible in Malaysia.

The findings from respondents and literature reveal that informing and getting support from the government was necessary for effective loan recovery. As noted from the above presentation, informing the local government is somehow unpopular compared to previously presented procedures with a higher agreement level. The context implies that, in loan recovery, all possible procedures are used as long as they lead to recovering loans. Even though they may seem unpleasant to a defaulting customer, they can serve the purpose.

\subsection{Use a Debt Collecting Agency}

In this section, the study's findings depict that most of the respondents who account for 26 (52\%) revealed that MFIs apply to a debt collection agency as a last resort for the loan recovery procedure. In 
line with the above findings, Gatimu et al. (2018) study on loan defaulting noted that loan recovery agencies are appropriate options to ensure loan recovery as sometimes it becomes difficult to recover money under normal conditions without external assistance. The above findings mean that the use of debt collection agencies to recover loans is among the procedures used by MFIs to implement loan recovery tasks. However, according to this study, this procedure is the fourth one, hence not as prominent as the previous three procedures. This finding implies that although this procedure is used, in most cases, credit officers recover loans earlier before using debt collection agencies for such an action. Impliedly, when this approach is used, it is meant to be the last resort that aims at preventing further losses on the side of the lender.

\subsection{Conclusion}

In light of the above findings, it is revealed that MFIs do apply several loan recovery procedures to ensure the extended amount to clients is returned in due time. The study categorically revealed various loan recovery procedures such as direct contact with customers, use of friendly reminders, issue of final demand notice, informing the local government authorities on property selling, and using a debt collection agency. Among all these loan recovery procedures, the most preferred loan recovery procedure is customers direct contact through phone and face-to-face contact, which is effective in loan recovery.

\subsection{Recommendations}

To make loan recovery smooth and effective, it is recommended that MFIs apply three things; first, ensure adherence to loan recovery practices as the government already sets forth the recovery procedures, and non-adherence implies a penalty. Secondly, MFIs should educate their customers on the loan recovery procedures and avoid taking issues personal then trigger verbal insults. Third, professional loan recovery saves costs and has higher effectiveness; thus, microfinance should learn and apply it during loan recovery assignment.

\section{References}

[1] Ali, H. M. A. (2014). Blaming the poor and legitimising coercive loan recovery strategies: Unveiling the dark side of NGO practices in Bangladesh. Anthropologica, 56(1).

[2] Amirah, A., \& Hanani, Y. (2018). The Current Practice of Debt Recovery Methods in Islamic Banks in Malaysia. International Journal of Islamic Studies. (Special Edition-SPIKESS, 13(2).

[3] Angaine, F., \& Waari, D. N. (2014). Factors Influencing Loan Repayment in Micro-Finance Institutions in Kenya (Vol. 16, Issue 9). Ver. III. www.iosrjournals.org

[4] BoT. (2019). Bank of Tanzania: Annual Report 2019/2020.

[5] Brown, A., Mackie, P., Smith, A., Msoka, C., Mwasekaga, B., Mongi, O., Japhet, P., Venance, T., Mkinga, N., \& Masiaya Laiser, Y. (2015a). Inclusive Growth: Tanzania Country Report Cardiff School of Geography and Planning Financial inclusion and microfinance in Tanzania Research Team Surveillance at the Bank of Tanzania, and of researchers.

[6] Brown, A., Mackie, P., Smith, A., Msoka, C., Mwasekaga, B., Mongi, O., Japhet, P., Venance, T., Mkinga, N., \& Masiaya Laiser, Y. (2015b). Inclusive Growth: Tanzania Country Report Cardiff School of Geography and Planning Financial inclusion and microfinance in Tanzania Research Team Surveillance at the Bank of Tanzania, and of researchers.

[7] Chen, X., Wang, G., \& Zhang, X. (2019). Modeling recovery rate for leveraged loans. Economic Modelling, 81. https://doi.org/10.1016/j.econmod.2019.04.006

[8] Chisom, A. (2012). Loan Granting and Its Recovery Problems on Commercial Banks (A Case Study of First Bank Plc, Ojo-Alaba Branch).

[9] CRDB. (2020). CRDB Annual Report 2019.

[10] Creswell, J. W., \& David Creswell, J. (2018). Research Design: Qualitative, Quantitative, and Mixed Methods Approaches (5th ed.). SAGE Publications.

[11] Debeb, D. (2015). A Study on Loan Recovery Performance of Rural Saving and Credit Cooperatives in Laygaint worda, Amhara Regional State, Ethiopia. In European Journal of Business and Management www.iiste.org ISSN (Vol. 7, Issue 25). Online. www.iiste.org

[12] Fenech, J. P., Yap, Y. K., \& Shafik, S. (2016). Modelling the recovery outcomes for defaulted loans: A 
[13] Gachuru, G. (2020). The Effect of Employee Competence on Performance of Microfinance Institutions in Nakuru Town. Editon Cons. J. Bus. Manag. Stud.-Blind Peer Reviewed Journal, 2(6), 40-48. www.editoncpublishing.org

[14] Gatimu, E. M., \& Kalui, F. M. (2014). Assessing Institutional Factors Contributing to Loan Defaulting in Microfinance Institutions in Kenya. IOSR Journal of Humanities and Social Science (IOSR-JHSS, 19(5), 105123. www.iosrjournals.org

[15] Gatimu, E. M., Muturi, W., \& Oluoch, O. (2018). Effect of Non-Performing Loan Management Practices on Loan Recovery Performance of Deposit Taking Savings and Credit Cooperatives in Kenya. IOSR Journal of Humanities and Social Science (IOSR-JHSS), 23(11).

[16] Gebeyehu, Z., Beshire, H., \& Haji, J. (2013). Determinants of Loan Repayment Performance of Smallholder Farmers: The Case of Kalu District, South Wollo Zone, Amhara National Regional State, Ethiopia. International Journal of Economics, Business and Finance, 1(11).

[17] Ghosh, S. (2019). Loan delinquency in banking systems: How effective are credit reporting systems? Research in International Business and Finance, 47. https://doi.org/10.1016/j.ribaf.2018.07.011

[18] Gikurumi, D. M., Ngahu, S. T., \& Wanyoike, D. (2015). Effects of Land Act 2012 On Recovery of Delinquent Loans by Commercial Banks in Kenya A Survey of Commercial Banks in Nakuru Town. International Journal of Economics, Commerce and Management United Kingdom, III (5).

[19] Guetterman, T. C., \& Fetters, M. D. (2018). Two Methodological Approaches to the Integration of Mixed Methods and Case Study Designs: A Systematic Review. American Behavioral Scientist, 62(7). https://doi.org/10.1177/0002764218772641

[20] Islam, R., Karim, Mohd. A., \& Ahmad, R. binti. (2018). Forced Loan-Recovery Technique of The Microfinance Institutes in Bangladesh And Its Impact on The Borrowers: An Empirical Study on Grameen Bank, Brac And Asa. Journal on Innovation and Sustainability. RISUS ISSN 2179-3565, 9(3). https://doi.org/10.24212/2179-3565.2018v9i3p75-93

[21] Kartikasary, M., Marsintauli, F., Serlawati, E., \& Laurens, S. (2020). Factors affecting the non-performing loans in Indonesia. Accounting, 6(2). https://doi.org/10.5267/j.ac.2019.12.003

[22] Kaveri, V. S. (2016). Strategic Debt Restructuring and Loan Recovery. Journal of Commerce and Management Thought, 7(2). https://doi.org/10.5958/0976-478x.2016.00015.x

[23] Khalily, M. A. B., \& Meyer, R. L. (1993). The political economy of rural loan recovery: evidence from Bangladesh. Savings \& Development, 17(1).

[24] Kimasar, F. (2014). The Use of Credit Reference Bureau on Loan Recovery Among Commercial Banks in Nakuru Town. International Journal of Science and Research, 3(10).

[25] Kiplimo, J. C. (2015). Determinants of access to credit by smallholder farmers in eastern and western Kenya. Journal of Development and Agricultural Economics, 7(9). https://doi.org/10.5897/JDAE2014.0591

[26] Kitomo, D., Likwachala, R., \& Swai, C. (2020). Financial Management Practices Among Micro Enterprises and their Implications for Loan Repayment: A Case of Solidarity Group Lending of DCB Commercial Bank in Dar es Salaam. International Journal of Economics and Finance, 12(12). https://doi.org/10.5539/ijef.v12n12p122

[27] Kosgey, Y. K. K. (2013). Agricultural Credit Access by Grain Growers in Uasin-Gishu County, Kenya. IOSR Journal of Economics and Finance, 2(3). https://doi.org/10.9790/5933-0233652

[28] Kothari, C. R. (2004). Research methodology: Methods and techniques (2nd ed.). New Age International (P), Ltd.

[29] Krishnan, R., \& Kozhikode, R. K. (2015). Status and corporate illegality: Illegal loan recovery practices of commercial banks in India. Academy of Management Journal, 58(5). https://doi.org/10.5465/amj.2012.0508

[30] Laseinde, M. A., \& Olokoyo, F. O. (2018). Deposit Money Banks Loan Recovery Strategies and CustomerBank Relationship. European Journal of Business, Economics and Accountancy, 6(3).

[31] Makorere, R. F. (2014). Factors affecting loan repayment behaviour in Tanzania: Empirical evidence from Dar es Salaam and Morogoro regions. International Journal of Development and Sustainability, 3(3).

[32] Marini, L., Andrew, J., \& van der Laan, S. (2017). Tools of accountability: protecting microfinance clients in South Africa? Accounting, Auditing and Accountability Journal, 30(6). https://doi.org/10.1108/AAAJ-042016-2548

[33] Mensah, H. K., Azinga, S. A., Akwele, J., \& Sodji, M. (2015). Challenges Faced by Small and Medium-Size Enterprises in Accessing Credit Facilities from Financial Institutions: An Empirical Assessment Incorporating the Perceptions of Both Borrowers and Financiers. In International Journal of Economics, Commerce and Management United Kingdom: Vol. III (Issue 11). http://ijecm.co.uk/

[34] Messai, A. S., \& Jouini, F. (2013). Micro and macro determinants of non-performing loans. International Journal of Economics and Financial Issues, 3(4). 
[35] MFT. (2011). Promoting Transparent Pricing in the Microfinance Industry TANZANIA Country Overview Key Facts: Microfinance in TANZANIA.

[36] Murthy, U., Mohammed Kamil, N., Anthony Mariadas, P., \& Devi, D. (2017). Factors Influencing NonPerforming Loans in Commercial Banks: The Case of Banks in Selangor. International Journal of Business and Management, 12(2). https://doi.org/10.5539/ijbm.v12n2p246

[37] Namayengo, F., van Ophem, J. A. C., \& Antonides, G. (2016). Women and microcredit in rural agrarian households of Uganda: Match or mismatch between lender and borrower? Applied Studies in Agribusiness and Commerce, 10(2-3). https://doi.org/10.19041/apstract/2016/2-3/9

[38] Neilands, R. (2018). Fictitious employment contracts in loan recovery processes in Latvia. SHS Web of Conferences, 40. https://doi.org/10.1051/shsconf/20184001005

[39] Netzer, O., Lemaire, A., \& Herzenstein, M. (2019). When Words Sweat: Identifying Signals for Loan Default in the Text of Loan Applications. Journal of Marketing Research, 56(6). https://doi.org/10.1177/0022243719852959

[40] Nguta Guyo, H., \& Huka, S. (2013). Factors Influencing Loan Repayment Default in Micro-Finance Institutions: The Experience of Imenti North District, Kenya. In International Journal of Applied Science and Technology (Vol. 3, Issue 3). www.ijastnet.com

[41] Okwara, M. O., Umebali, E. E., Agu, F. N., \& Anyanwu, U. G. (2019). Efficiency of Microfinance Banks' Lending to Agriculture in Imo State, Nigeria. Asian Journal of Agricultural Extension, Economics \& Sociology. https://doi.org/10.9734/ajaees/2019/v36i230242

[42] Ongesa, N. t, Nyamweya.B.O, Abdi, M. A., Njeru, F., \& Gongera, E. G. (2014). An Assessment of Financial Literacy on Loan Repayment by Small and Medium Entrepreneurs in Ngara, Nairobi County. Research Journal of Finance and Accounting, 5(12).

[43] Osunde, C., \& Mayowa, A. G. (2012). Microfinance and Entrepreneurial Development in Nigeria. In Jorind (Vol. 10, Issue 3).

[44] Ozili, P. K. (2019). Non-performing loans and financial development: new evidence. Journal of Risk Finance, 2O(1). https://doi.org/10.1108/JRF-07-2017-0112

[45] Pandey, A. (2019). High bids and low recovery: A possible case for non-performing loan auctions in India. IIMB Management Review, 31(3). https://doi.org/10.1016/j.iimb.2019.03.005

[46] Paxton, J., Graham, D., \& Thraen, C. (2000). Modeling group loan repayment behavior: New insights from Burkina Faso. Economic Development and Cultural Change, 48(3). https://doi.org/10.1086/452613

[47] Priyankara, D. T., \& Sumanasiri, E. A. G. (2019). Determinants of Microfinance Loan Default: An Empirical Investigation in Sri Lanka. South Asian Journal of Social Studies and Economics. https://doi.org/10.9734/sajsse/2019/v4i330127

[48] Rao, D. S., \& Sravani, M. (2013). Self-Regulatory Organisations in Indian Microfinance Sector. International Journal of Management \& Information Technology, 7(1). https://doi.org/10.24297/ijmit.v7i1.712

[49] Rathnapala, I. (2015). Law and Practice Relating to Money Recovery Actions in Sri Lanka. SSRN Electronic Journal. https://doi.org/10.2139/ssrn.2598345

[50] Rehman, R. U., Zhang, J., \& Ahmad, M. I. (2016). Political system of a country and its non-performing loans: A case of emerging markets. International Journal of Business Performance Management, 17(3). https://doi.org/10.1504/IJBPM.2016.077243

[51] Risal, N. (2018). Microfinance Position and Indebtedness: Empirical Evidence from Microfinance Institutions in Nepa. Pravaha, 24(1). https://doi.org/10.3126/pravaha.v24i1.20232

[52] Sah, R. (2015). Loan Recovery Monitoring Mechanism. International Journal of Trade, Economics and Finance, 6(1). https://doi.org/10.7763/ijtef.2015.v6.444

[53] Sarma, G. K., \& Borbora, S. (2014). Loan Recovery Performance of Credit Officers in Microfinance Institutions: A Case of Assam. In International Journal of Science and Research. www.ijsr.net

[54] THOMAS, R., \& Thakur, S. S. (2019). Bank-group wise Comparison of Loan Recovery Performance of Commercial Banks in India. International Journal of Business Excellence, 1(1). https://doi.org/10.1504/ijbex.2019.10023278

[55] Torban, T. K. (2020). Assessment of Credit Risk Management in Micro Finance Institutions: A Case of Adama Town MFIs, Ethiopia. Srusti Management Review, 13(1).

[56] URT. (2000). The Tanzania Development Vision 2025.

[57] Microfinance Act, (2018).

[58] Microfinance Regulations, (2019).

[59] Wang, H., Forbes, C. S., Fenech, J. P., \& Vaz, J. (2020). The determinants of bank loan recovery rates in good times and bad - New evidence. Journal of Economic Behavior and Organization, 177. https://doi.org/10.1016/j.jebo.2020.06.001

[60] Waqas, M., Fatima, N., Khan, A., \& Arif, M. (2019). Determinants of Non-performing Loans. International 
Journal of Finance \& Banking Studies (2147-4486), 6(1). https://doi.org/10.20525/ijfbs.v6i1.617

[61] WB. (2013). Diagnostic Review of Consumer Protection and Financial Literacy: Key Findings and Recommendations, Financial Inclusion and Infrastructure Practice, Financial Inclusion and Consumer Protection Service Line, Africa Region.

[62] Wilfred, C. (2013). Evaluating the State of Loan Repayment on Management of Microfinance Institutions: A Case of National Microfinance Bank.

[63] Yegon, J. C., Kipkemboi, J., Kemboi, J. K., \& Chelimo, K. K. (2013). Determinants of Seasonal Loan Default among Beneficiaries of a State-Owned Agricultural Loan Scheme in Uasin Gishu County, Kenya. Journal of Emerging Trends in Economics and Management Sciences, 5(1).

[64] Zhang, Y., Shi, B., Wei, Y., \& Jin, D. (2019). Loans defaulting prematurely and the pricing of loan insurance. Xitong Gongcheng Lilun $Y u$ Shijian/System Engineering Theory and Practice, 39(10). https://doi.org/10.12011/1000-6788-2018-0381-10 